Journal of EST, Volume 1, Nomor 1 Juni 2015 hal 39- 53

ISSN:2460-1497

\title{
IMPLEMENTASI MODEL POLA ASUH ORANGTUA UNTUK MENINGKATKAN KEMANDIRIAN ANAK
}

\author{
Kustiah Sunarty \\ Ahli bimbingan konseling \\ FIP Universitas Negeri Makassar, Indonesia \\ ksunarty@gmail.com
}

\begin{abstract}
This study aimed at examining the implementation of Parenting Model to enhance children's self-reliancelautonomy (PAO-MKA Model), for junior high school students. PAO-MKA Model is developed by Sunarty (2014) and has been tested both for its validity and practicality. It was found that the Model has a high degree of validity. The purpose of the study was to find out the effectiveness of PAO-MKA Model to improve children's self-reliance. This study used quantitative approach with pre-experimental study. The model used one group of pretest and posttest design. The experiment was conducted at SMPN 8 Makassar. The research subject was divided into two groups, a group of parents and a group of children, consisted of 30 people respectively. The group of parents were used to examine how they implement the PAO-MKA Model. The group of children were required to measure the level of children's self-reliance. The data were analyzed using t-test or mean difference test. The results of the study showed that there was a positive and significant difference on children's self-reliance before and after the implementation of PAO-MKA Model and could be concluded that the PAO-MKA Model is effective to improve children's self-reliance.
\end{abstract}

Key words: self-reliance, parenting, PAO-MKA Model.

\begin{abstract}
ABSTRAK
Penelitian ini mengkaji implementasi Model Pola Asuh Orangtua untuk Meningkatkan Kemandirian Anak (PAO-MKA) di SMP Makassar. Model PAO-MKA dikembangkan oleh Sunarty (2014), dan telah melalui uji validitas ahli dan praktisi/Guru BK, dan hasilnya valid, dan siap diimplemantasikan. Permasalahan penelitian adalah apakah Model PAO-MKA efektif meningkatkan kemandirian anak?. Tujuan penelitian adalah untuk mengetahui keefektifan Model PAO-MKA dalam upaya meningkatkan kemandirian anak. Penelitian ini menggunakan pendekatan kuantitatif, dengan jenis penelitian pra-experimental, model one group pretestposttes design. Eksperimen dilaksanakan di SMPN 8 Makassar. Subyek penelitian terbagi ke dalam dua kelompok, yakni kelompok anak dan orangtuanya, masing-masing berjumlah 30 orang. Subyek anak diperlukan dalam kaitannya dengan pengukuran tingkat kemandirian anak. Sementara subyek orangtua diperlukan dalam kaitannya dengan implementasi Model PAOMKA. Data dianalisis dengan uji statistik inferensial, yakni uji t atau uji perbedaan mean. Hasil penelitian menunjukkan bahwa terdapat perbedaan yang positif dan signifikan antara tingkat kemandirian anak sebelum (pretest) dan sesudah (posttest) pelatihan dan penerapan model PAO-MKA. Dengan adanya perbedaan tersebut maka Model PAO-MKA dinyatakan efektif meningkatkan kemandirian anak.
\end{abstract}

Kata kunci: kemandirian, pola asuh, model PAO-MKA 


\section{PENDAHULUAN}

Kemandirian sering diartikan sebagai self
reliance, freedom (kemerdekaan), otonom
(autonomy), dan bebas (independent). Kemandirian didefinisikan sebagai hal atau keadaan dapat berdiri sendiri tanpa bergantung kepada orang lain" (Depdiknas, 2000: 155). Banyak anak yang tidak mandiri karena orangtua memiliki cara pandang yang keliru terhadap anak, yakni "Anak adalah bentuk kecil dari orang dewasa" (Al-Istanbuli, 2006), Pendapat ini, masih banyak dijumpai di Indonesia, bahkan diyakini oleh banyak orang bahwa instink, minat, hasrat, dan cara berpikir anak (siswa) sama dengan orang dewasa, yang berbeda hanyalah bentuk fisiknya. Akibat dari cara pandang tersebut, banyak anak mengalami "goncangan" karena tuntutan yang ditimpakan pada mereka kurang sesuai dengan keadaan yang sesungguhnya. Dampak lainnya adalah "komunikasi menjadi buntu" (Gordon, 2000).

Perilaku mandiri adalah hasil dari proses pembelajaran baik yang berasal dari lingkungan keluarga maupun lingkungan yang lebih luas. $\mathrm{Ki}$ Hadjar Dewantara mengemukakan kemandirian adalah manusia merdeka yaitu manusia yang hidupnya lahir dan batin tidak tergantung kepada orang lain, tetapi berdasar atas kekuatan sendiri (Suryono, 2013). Kemandirian mengandung makna suatu penghayatan/semangat untuk menjadi lebih baik, memiliki sikap dan perilaku: percaya diri, disiplin, bertanggung jawab, mengelola pikiran dalam menelaah masalah yang dihadapi guna mengambil keputusan, dan berani mengambil risiko dari keputusannya (Dariyo, 2007).

Fenomena-fenomena yang terjadi akhirakhir ini baik yang ditayangkan melalui media elektronik maupun media cetak, memperlihatkan perilaku pelajar yang sangat membutuhkan perhatian dunia pendidikan, seperti perkelahian antarpelajar, penyalahgunaan obat dan alkohol, perilaku agresif, dan berbagai perilaku menyimpang yang sudah mengarah ke tindak kriminal. Fenomena perilaku seperti itu menunjukkan betapa anak-anak tersebut menunjukkan ketidakmampuannya di dalam mengambil keputusan terhadap berbagai hal yang terjadi di sekitarnya dalam kehidupannya seharihari. Desmita (2009) mengemukakan bahwa dalam konteks proses belajar, terlihat adanya fenomena anak yang kurang mandiri dalam belajar, yang dapat menimbulkan gangguan mental setelah memasuki pendidikan lanjutan, memiliki kebiasaan belajar yang kurang baik, seperti: tidak betah belajar lama atau belajar hanya menjelang ujian, membolos, menyontek, dan mencari bocoran soal-soal ujian.

Berdasar pada fenomena tersebut jika tidak segera diatasi maka akan menimbulkan dampak yang lebih besar, yakni akan merusak masa depan anak itu sendiri dan pada akhirnya akan berdampak pada lingkungan yang lebih luas. Hal ini diperkuat oleh hasil penelitian, Astuti (2005), Astuti (2009) dan Marjohan (2009) bahwa anak yang tidak mandiri akan menyusahkan dirinya dan orang lain, cenderung tidak percaya diri dan tidak mampu menyelesaikan tugas hidupnya dengan baik. Banyak faktor penyebab anak tidak mandiri. Salah satu penyebab anak tidak mandiri adalah pola asuh orangtua dalam keluarga (Ali \& Asrori, 2008; Eviana, 2004; Rahmawaty, 2009; Latifatul, 2011). Hasil survei pendahuluan Sunarty (2014) mengungkapkan bahwa pola asuh yang dapat meningkatkan kemandirian anak adalah pola asuh positif dan demokratis. Berdasar pada temuan itu muncul ide membuat Model PAO-MKA untuk meningkatkan kemandirian anak. Isi/materi Model PAO-MKA didasarkan pada teori pola asuh orangtua psositif dan demokratis. Pola asuh orangtua positif (positive parenting) merujuk pada teori kepribadian Transactional Analysis Eric Berne (James, 2002) dan pola asuh orangtua demokratis merujuk pada 
Sunarty, implementasi model pola asuh... 41

teori ekologi (lingkungan) Bronfenbrenner (Santrock, 2009).

Tujuan kegiatan pelatihan Model PAOMKA adalah untuk membantu orangtua dalam upaya meningkatkan kemandirian anaknya. Keterampilan-keterampilan yang dilatihkan berkaitan dengan pola asuh orangtua. positif dan demokratis. Pola asuh orangtua tampak dalam ucapan dan tindakan orangtua ketika berkomunikasi, bertransaksi atau berinteraksi dengan anak. Materi pelatihan Model PAOMKA berisi keterampilan yang berkaitan dengan pola asuh orangtua (ucapan-ucapan dan tindakantindakan) yang dapat meningkatkan kemandirian anak, melalui komunikasi antarpribadi dalam kehidupan sehari-hari (Gordon, 2000). Pelatihan Model PAO-MKA dilakukan dengan prinsip "belajar melalui pengalaman". Pertimbangannya adalah belajar dengan mengalami dapat memberikan hasil belajar yang relatif menetap dan optimal. Atas dasar tersebut, dirumuskan hipotesis "apakah Model PAO-MKA efektif meningkatkan kemandirian anak"?

\section{METODE PENELITIAN}

Penelitian ini menggunakan pendekatan kuantitatif. Jenis penelitian adalah eksperimen (pra-experimental), model one group pretestposttes design. Ruang lingkup pola asuh orangtua dan kemandirian anak. Rancangan penelitian dapat dilihat pada gambar 01 .

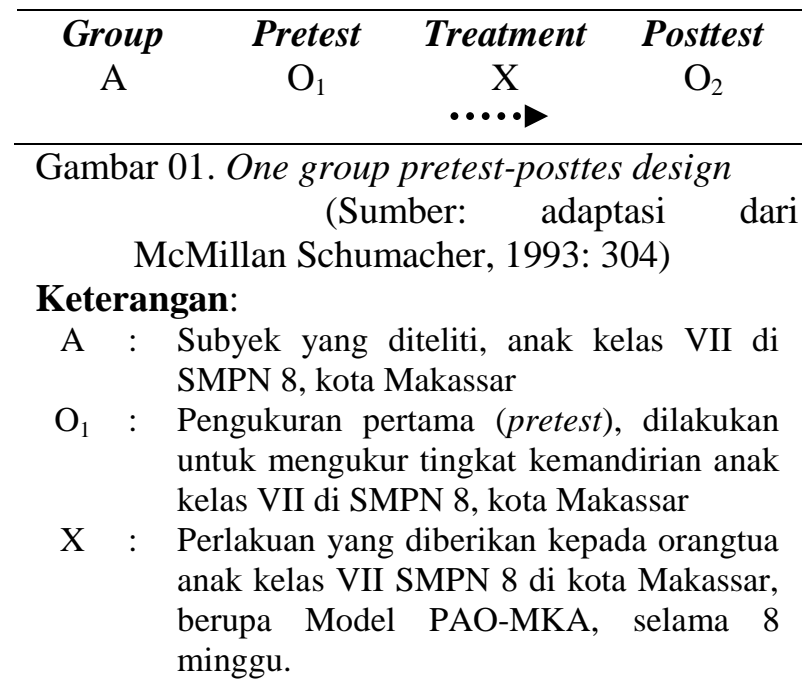

$\mathrm{O}_{2}$ : Pengukuran kedua (posttest) dilakukan untuk mengukur tingkat kemandirian anak kelas VII di SMPN 8, kota Makassar

Rentang waktu (8 minggu) pelaksanaan Model PAO-MKA

Bahan perlakuan terdapat dalam Prototipe Model PAO-MKA. Bahan perlakuan berupa skenario pelaksanaan Model yang terangkum dalam panduan umum dan panduan khusus. Panduan umum berbentuk naskah tertulis yang berisi uraian yang memaparkan Model, meliputi: rasional, tujuan, sasaran, sistematika kegiatan dan alokasi waktu, tempat, dan karakteristik subyek penelitian. Panduan khusus berbentuk naskah tertulis, yang berisi prosedur pelaksanaan penerapan Model PAO-MKA.

Alat yang digunakan dalam pengumpulan data, meliputi:

a) Skala kemandirian, digunakan untuk memperoleh informasi mengenai perkembangan kemandirian anak setelah penerapan Model PAO-MKA oleh orangtuanya, terutama dalam kaitannya dengan hasil post-test.

b) Observasi, digunakan untuk melihat keterlaksanaan pelatihan/simulasi Model PAO-MKA. Pelaksanaan observasi menggunakan Pedoman Observasi.

c) Wawancara, digunakan terutama untuk menjaring informasi yang berkaitan dengan penerapan Model PAO-MKA berdasar pengetahuan, keterampilan atau pengalaman subyek penelitian baik orangtua maupun anak SMP, serta tanggapan dan penilaian mereka terhadap Model PAO-MKA

d) Focus Group Discussion (FGD) digunakan untuk menjaring informasi dari para orangtua antara lain: (1) pemahaman dan tanggapan mereka terhadap konsep pola asuh orangtua dan kemandirian anak dalam Model PAOMKA; (2) tanggapan-tanggapan, yang berkaitan dengan pengembangan Model PAOMKA, dan (3) pengalaman serta kebiasaan subjek sekitar penerapan Model PAO-MKA.

e) Checklist, digunakan untuk mengetahui tingkat penguasaan orangtua setelah melalui pelatihan Model PAO-MKA. 
Tempat penelitian dilaksanakan di kota Makassar pada Sekolah Menengah Pertama (SMPN 8). Teknik pengumpulan data menggunakan angket/skala kemandirian.

Variabel penelitian ini terdiri atas dua, yakni:

a) Kemandirian adalah kemampuan anak mengambil keputusan sendiri terhadap kebutuhannya dalam kehidupan sehari-hari, yang ditandai dengan sikap dan perilaku percaya diri, disiplin, bertanggung jawab, berpikir positif dalam menelaah dan memecahkan masalah yang dihadapi, serta berani mengambil risiko dari keputusannya.

b) Model PAO-MKA ialah kerangka konseptual yang melukiskan prosedur sistematis dalam mengorganisasi kegiatan pelatihan, dan berfungsi sebagai pedoman dalam merencanakan dan menjalankan program pelatihan.

Teknik analisis data menggunakan analisis kuantitatif dan kualitatif, meliputi:

a) Teknik persentase digunakan umtuk menganalisis keaktifan peserta pelatihan melalui Pedoman Observasi, dan mendeskripsikan penguasaan orangtua melalui cheklist terhadap Model PAO-MKA.

b) Analisis deskriptif kualitatif (naratif) digunakan untuk menganalisis data perubahan perilaku pola asuh orangtua sesudah diberi pelatihan dan penerapan model PAO-MKA.

c) Uji t (uji perbedaan Mean) untuk menganalisis keefektifan Model PAO-MKA dalam upaya meningkatkan kemandirian anak.

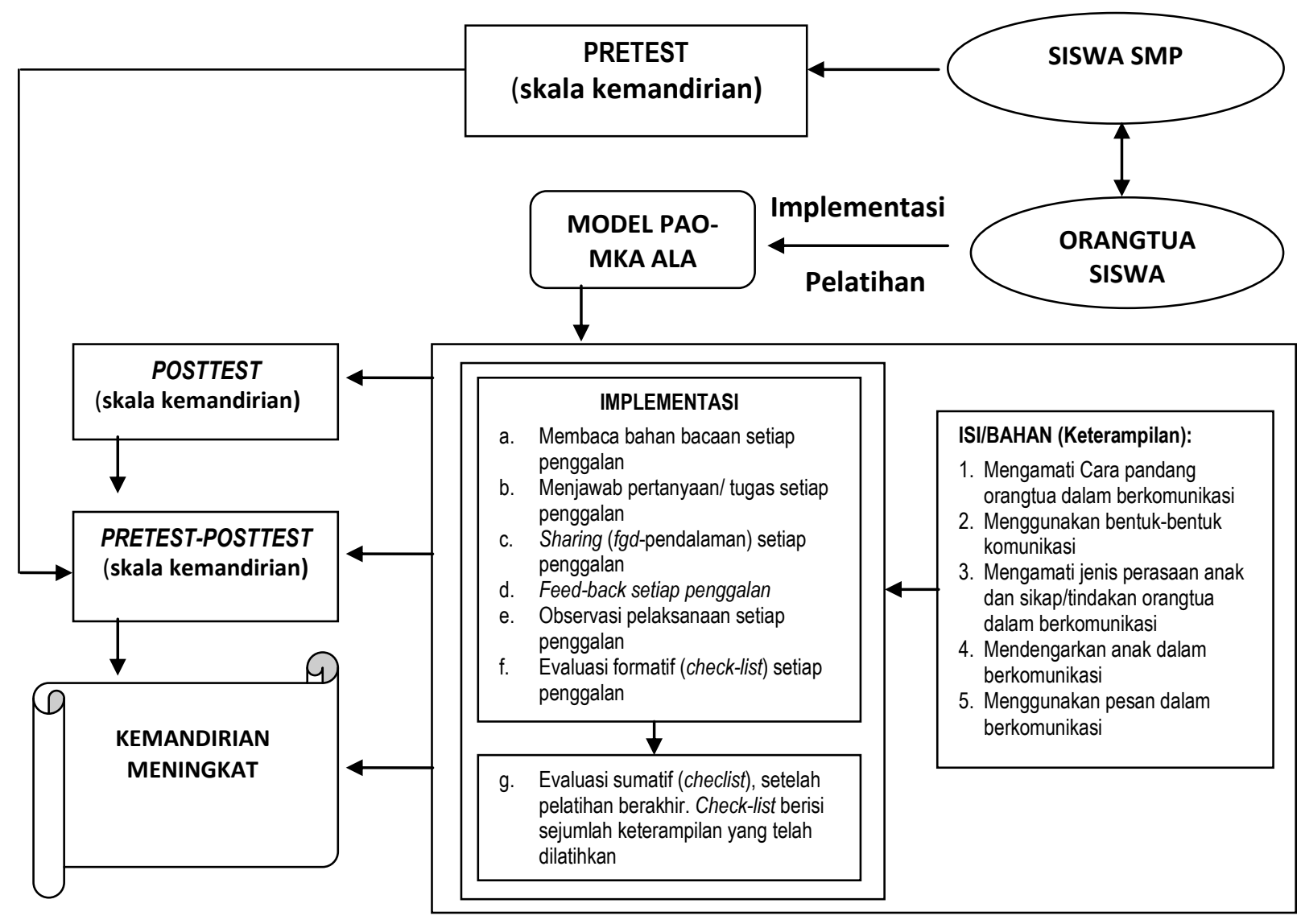

Gambar 2. Kerangka Prosedur penelitian eksperimen 


\section{HASIL DAN PEMBAHASAN}

\section{Hasil}

Deskripsi Model Pola Asuh ORANGTUA.Implementasi Model PAO-MKA terhadap orangtua $(\mathrm{N}=30)$, dipaparkan dalam tabel 01, sebagai berikut:

Tabel 01. Rangkuman Hasil Pelatihan Model PAO-MKA (N=30)

\begin{tabular}{|c|c|c|c|}
\hline \multicolumn{4}{|c|}{ Penggalan 1. Cara pandang Orangtua dalam berkomunikasi } \\
\hline $\begin{array}{l}\text { Keterampilan } \\
\text { Mengamati }\end{array}$ & Prapelatihan & Pelatihan & Pascapelatihan \\
\hline $\begin{array}{l}\text { Cara pandang } \\
\text { Orangtua } \\
\text { terhadap anak }\end{array}$ & $\begin{array}{l}\text { 1. Anak sama } \\
\text { dengan orang } \\
\text { dewasa dalam } \\
\text { bentuk kecil } \\
\text { 2. Memelihara dan } \\
\text { membimbing } \\
\text { anak hanya } \\
\text { berdasar pada } \\
\text { pengalaman yang } \\
\text { diterima dari } \\
\text { orangtua mereka, } \\
\text { tanpa } \\
\text { memperhatikan } \\
\text { kebutuhan } \\
\text { perkembangan } \\
\text { anak. }\end{array}$ & $\begin{array}{l}\text { Melatih keterampilan } \\
\text { mengamati: Cara } \\
\text { pandang Orangtua } \\
\text { terhadap anak, melalui } \\
\text { pemberian contoh dalam } \\
\text { bentuk } \\
\text { Deskripsi kasus }\end{array}$ & $\begin{array}{l}\text { Orangtua menyadari kekeliruannya dan } \\
\text { bersedia memperbaiki atau } \\
\text { mengubahnya menjadi cara pandang } \\
\text { yang benar dan menerapkannya dalam } \\
\text { kehidupan sehari-hari ketika } \\
\text { berkomunikasi:: } \\
\text { 1. Anak siap bertumbuh berkembang } \\
\text { sesuai dengan potensinya } \\
\text { 2. Pengalaman pola asuh yang } \\
\text { diterima di dalam keluarga asal, } \\
\text { bisa diubah. } \\
\text { 3. Pola asuh bisa diubah melalui } \\
\text { proses belajar }\end{array}$ \\
\hline $\begin{array}{l}\text { Cara pandang } \\
\text { orangtua } \\
\text { terhadap } \\
\text { konsistensi }\end{array}$ & $\begin{array}{l}\text { 1. "Tidak boleh } \\
\text { berubah" dalam } \\
\text { situasi dan } \\
\text { kondisi apapun. } \\
\text { 2. Kewajiban anak } \\
\text { harus tunduk } \\
\text { kepada orangtua, } \\
\text { 3. Anak harus diajari } \\
\text { kepatuhan, } \\
\text { norma-norma } \\
\text { yang } \\
\text { mengharuskan } \\
\text { anak mengikuti } \\
\text { anjuran orangtua. }\end{array}$ & $\begin{array}{l}\text { Cara pandang Orangtua } \\
\text { terhadap konsistensi } \\
\text { melalui pemberian } \\
\text { contoh dalam bentuk } \\
\text { Deskripsi kasus: } \\
\text { 1. Berkaitan dengan } \\
\text { suasana hati orangtua } \\
\text { 2. Berkaitan dengan } \\
\text { karakteristik anak } \\
\text { 3. Berkaitan dengan } \\
\text { lingkungan/tempat } \\
\text { terjadinya peristiwa. }\end{array}$ & $\begin{array}{l}\text { Orangtua sadar bahwa tidak ada } \\
\text { orangtua bisa konsisten seumur hidup. } \\
\text { Oleh karena itu orangtua harus mau } \\
\text { mengubah pemahamannya, dengan } \\
\text { pertimbangan: } \\
\text { 1. Konsistensi sangat dipengaruhi oleh } \\
\text { suasana hati orangtua } \\
\text { 2. Konsistensi sangat dipengaruhi oleh } \\
\text { karakteristik anak } \\
\text { 3. Konsistensi sangat dipengaruhi oleh } \\
\text { lingkungan/tempat terjadinya } \\
\text { peristiwa. }\end{array}$ \\
\hline
\end{tabular}




\begin{tabular}{|c|c|c|c|}
\hline $\begin{array}{l}\text { Cara pandang } \\
\text { orangtua } \\
\text { terhadap } \\
\text { "siapa" } \\
\text { pemilik } \\
\text { masalah }\end{array}$ & $\begin{array}{l}\text { Pemahaman orangtua } \\
\text { tentang siapa pemilik } \\
\text { masalah adalah: } \\
\text { 1. "anak yang selalu } \\
\text { menimbulkan } \\
\text { masalah", } \\
\text { 2. anak yang harus } \\
\text { berubah, bukan } \\
\text { orangtua. }\end{array}$ & $\begin{array}{l}\text { Cara pandang Orangtua } \\
\text { terhadap siapa pemilik } \\
\text { masalah melalui } \\
\text { pemberian contoh dalam } \\
\text { bentuk Deskripsi kasus: } \\
\text { Berkaitan dengan } \\
\text { permasalahan yang } \\
\text { sering dialami anak }\end{array}$ & $\begin{array}{l}\text { Telah terjadi perubahan pemahaman } \\
\text { orangtua tentang siapa pemilik masalah } \\
\text { adalah: } \\
\text { 1. "anak yang memiliki masalah jika } \\
\text { masalah tsb tidak menimbulkan } \\
\text { masalah bagi orangtua", } \\
\text { 2. "orangtua yang memiliki masalah } \\
\text { jika masalah anak menimbulkan } \\
\text { persoalan bagi orangtua", }\end{array}$ \\
\hline
\end{tabular}

\begin{tabular}{|c|c|c|c|}
\hline \multicolumn{4}{|c|}{ Penggalan 2. Keterampilan mengamati bentuk-bentuk komunikasi } \\
\hline $\begin{array}{l}\text { Bentuk respon } \\
\text { dan tindakan } \\
\text { orangtua } \\
\text { dalam } \\
\text { berkomu- } \\
\text { nikasi }\end{array}$ & $\begin{array}{l}\text { Orangtua dalam } \\
\text { merespon dan } \\
\text { bertindak } \\
\text { menggunakan ucapan } \\
\text { dan tindakan penuh } \\
\text { dengan kritikan, } \\
\text { nasihat, peringatan, } \\
\text { anjuran, dan perintah. }\end{array}$ & $\begin{array}{l}\text { Melatih keterampilan } \\
\text { tentang cara merespon } \\
\text { atau bertindak dengan } \\
\text { memberikan contoh } \\
\text { deskripsi kasus. } \\
\text { Tanggapan verbal } \\
\text { orangtuan sering dirtikan } \\
\text { anak lebih dari satu: } \\
\text { 1. Anak mengatakan } \\
\text { tentang dirinya } \\
\text { (ditolak atau diterima) } \\
\text { 2. Hubungan antara } \\
\quad \text { dirinya dan } \\
\text { orangtuanya } \\
\text {.(kesalahpahaman) }\end{array}$ & $\begin{array}{l}\text { Telah terjadi perubahan cara merespon } \\
\text { sesuai dengan jenis permasalahan anak, } \\
\text { dengan cara: } \\
\text { - menggunakan bahasa penerimaan, } \\
\text { berupa ucapan dan tindakan wajar, } \\
\text { apa adanya, mendorong, } \\
\text { membimbing, rileks (konstruktif) } \\
\text { dalam berkomunikasi, } \\
\text { - menghindari bahasa penolakan } \\
\text { (destruktif) yang dapat menimbulkan } \\
\text { dampak jelek pada anak. }\end{array}$ \\
\hline $\begin{array}{l}12 \text { Ciri } \\
\text { pembuntu } \\
\text { komunikasi } \\
\text { dan } \\
\text { dampaknya } \\
\text { terhadap anak } \\
\text { dalam } \\
\text { berkomu- } \\
\text { nikasi }\end{array}$ & $\begin{array}{l}\text { Hampir semua } \\
\text { orangtua lebih sering } \\
\text { menggunakan "12 } \\
\text { Ciri Pembuntu } \\
\text { komunikasi" dalam } \\
\text { berkomunikasi: } \\
\text { Memerintah, } \\
\text { mengancam, } \\
\text { mendesak, } \\
\text { menasihati, } \\
\text { mengajari, menilai, } \\
\text { memuji, mencemoh, } \\
\text { menganalisis, } \\
\text { meyakinkan, } \\
\text { menyelidiki, \& } \\
\text { menghindar }\end{array}$ & $\begin{array}{l}\text { Melatih keterampilan } \\
\text { tentang cara bersikap dan } \\
\text { bertindak dengan } \\
\text { memberikan contoh } \\
\text { deskripsi kasus tentang } \\
\text { cara berkomunikasi } \\
\text { (Analisis } \\
\text { Transaksional): }\end{array}$ & $\begin{array}{l}\text { Telah terjadi perubahan di dalam } \\
\text { menyikapi dan menindaki } \\
\text { permasalahan anak, dengan cara: } \\
\text { 1. membiarkan anak mengungkap } \\
\text { permasalahnnya secara utuh yang } \\
\text { dialaminya (here and now), dengan } \\
\text { menggunakan Adult dan direspon } \\
\text { orangtua dengan cara yang sama } \\
\text { (Adult), sesuai dengan jenis } \\
\text { permasalahan anak. } \\
\text { 2. Meminimalkan menggunakan “12 } \\
\text { ciri pembuntu komunikasi” agar } \\
\text { komunikasi terjalin dengan baik. }\end{array}$ \\
\hline
\end{tabular}

\begin{tabular}{llll}
\hline Penggalan 3. & Keterampilan mengamati jenis perasaan anak dan sikap/tindakan orangtua dalam \\
berkomunikasi & & \\
\hline $\begin{array}{l}\text { Jenis-jenis } \\
\text { perasaan }\end{array}$ & Hampir semua & Melatih orangtua & Orangtua telah memahami dan berupaya \\
anak dalam & memptua tidak & keterampilan mengamati & mengenal jenis perasaan anak, antara \\
berkomu- & perasaan anak & perasaan anak ketika anak & lain: bingung, kecewa, kesal, sedih, \\
nikasi & ketika & mengungkap & cemas, senang, gembira.
\end{tabular}




\begin{tabular}{|c|c|c|c|}
\hline & berkomunikasi & $\begin{array}{l}\text { memberikan contoh } \\
\text { deskripsi kasus yang } \\
\text { berkaitan dengan perasaan. }\end{array}$ & \\
\hline $\begin{array}{l}\text { Sikap dan } \\
\text { Tindakan } \\
\text { Orangtua } \\
\text { dalam } \\
\text { berkomu- } \\
\text { nikasi }\end{array}$ & $\begin{array}{l}\text { Hampir semua } \\
\text { orangtua bersikap } \\
\text { dan bertindak } \\
\text { sesuai dengan } \\
\text { perasaannya, bukan } \\
\text { perasaan anak } \\
\text { ketika } \\
\text { berkomunikasi }\end{array}$ & $\begin{array}{l}\text { Melatih orangtua } \\
\text { keterampilan bersikap dan } \\
\text { bertindak sesaui dengan } \\
\text { perasaan anak dengan } \\
\text { memberikan contoh } \\
\text { deskripsi kasus yang } \\
\text { berkaitan dengan perasaan } \\
\text { anak, dengan cara } \\
\text { merefleksikan } \\
\text { permasalahan anak tersebut } \\
\text { ke dalam dirinya sebelum } \\
\text { mengambil sikap/bertindak }\end{array}$ & $\begin{array}{l}\text { Orangtua telah menyadari kekeliruannya } \\
\text { dan berupaya mengenal jenis perasaan } \\
\text { anak, sebelum bersikap dan bertindak., } \\
\text { antara lain: } \\
\text { 1. empati terhadap perasaan bingung, } \\
\text { kecewa, kesal, sedih, cemas, senang, } \\
\text { gembira. } \\
\text { 2. terbuka/koperatif menerima kritikan } \\
\text { anak }\end{array}$ \\
\hline \multicolumn{4}{|c|}{ Penggalan 4. Keterampilan mendengarkan anak dalam berkomunikasi } \\
\hline $\begin{array}{l}\text { Teknik- } \\
\text { teknik } \\
\text { mendengark } \\
\text { an dasar } \\
\text { dalam } \\
\text { berkomu- } \\
\text { nikasi }\end{array}$ & $\begin{array}{l}\text { Hampir semua } \\
\text { orangtua tidak } \\
\text { menyediakan waktu } \\
\text { khusus } \\
\text { mendengarkan } \\
\text { permasalahan anak, } \\
\text { langsung } \\
\text { memberikan jalan } \\
\text { ke luar sesuai } \\
\text { dengan maunya } \\
\text { orangtua. }\end{array}$ & $\begin{array}{l}\text { Melatih orangtua } \\
\text { keterampilan dasar } \\
\text { mendengarkan anak } \\
\text { dengan memberikan contoh } \\
\text { deskripsi kasus yang } \\
\text { berkaitan dengan: } \\
\text { 1. Diam (mendengar } \\
\text { pasif) } \\
\text { 2. Memberi mengiyakan / } \\
\text { dorongan minimal } \\
\text { 3. Membuka pintu atau } \\
\text { ajak berbicara }\end{array}$ & $\begin{array}{l}\text { - Orangtua telah menyadari } \\
\text { kekeliruannya yang tidak menyediakan } \\
\text { waktu khusus dan berupaya mengubah } \\
\text { diri dengan cara menyediakan waktu } \\
\text { khusus mendengar ungkapan perasaan } \\
\text { anak, dan menerapkan tiga teknik } \\
\text { dalam berkomunikasi. }\end{array}$ \\
\hline $\begin{array}{l}\text { Mendengar } \\
\text { aktif dan } \\
\text { penerapanny } \\
\text { a dalam } \\
\text { berkomu- } \\
\text { nikasi }\end{array}$ & $\begin{array}{l}\text { Hampir semua } \\
\text { orangtua tidak } \\
\text { mengetahui apa itu } \\
\text { "mendengar aktif".. }\end{array}$ & $\begin{array}{l}\text { Melatih orangtua } \\
\text { keterampilan mendengar } \\
\text { aktif, yang dimulai dengan } \\
\text { memberikan contoh } \\
\text { deskripsi kasus, yang } \\
\text { dimulai dengan: } \\
\text { 1. anak bercerita tentang } \\
\text { permasalahan yang baru } \\
\text { saja dialaminya (here \& } \\
\text { now) berkaitan dengan } \\
\text { perasaanya, dan biasanya } \\
\text { menggunakan kata sandi. } \\
\text { 2. Orangtua dilatih } \\
\text { merespon bahasa sandi } \\
\text { anak, mengurai bahasa } \\
\text { sandi tersebut dengan } \\
\text { cara memantul balikkan } \\
\text { perasaan itu sesuai yang } \\
\text { dirasakan anak } \\
\text { 3. Jika pantulan balik itu } \\
\text { benar, anak akan meng- } \\
\text { iyakan, tapi jika keliru, }\end{array}$ & $\begin{array}{l}\text { - Orangtua telah menyadari } \\
\text { kekeliruannya yang selalu memberikan } \\
\text { solusi secara terburu-buru, tanpa } \\
\text { mendengar ungkapan perasaan anak. } \\
\text { - Orangtua mau dan mulai menerapkan } \\
\text { keterampilan mendengar aktif dengan } \\
\text { mengamati dan mengurai bahasa sandi } \\
\text { anak sebelum memberikan solusi } \\
\text { terhadap permasalahan anak. }\end{array}$ \\
\hline
\end{tabular}


anak menyanggahnya, dan orangtua harus mengurai bahasa sandi tersebut sampai benar

\begin{tabular}{|c|c|c|c|}
\hline \multicolumn{4}{|c|}{ Penggalan 5. Keterampilan menggunakan pesan dalam berkomunikasi } \\
\hline $\begin{array}{l}\text { Penggunaan } \\
\text { Pesan Kamu } \\
\text { dalam } \\
\text { berkomuni- } \\
\text { kasi }\end{array}$ & $\begin{array}{l}\text { Hampir semua } \\
\text { orangtua } \\
\text { menggunakan } \\
\text { bahasa kamu dalam } \\
\text { berkomunikasi, dan } \\
\text { mengamati } \\
\text { permasalahan anak } \\
\text { dari sudut pandang } \\
\text { orangtua, sehingga } \\
\text { menimbulkan } \\
\text { masalah pada anak } \\
\text { dan orangtua. }\end{array}$ & $\begin{array}{l}\text { Melatih orangtua } \\
\text { keterampilan menggunakan } \\
\text { pesan kamu yang positif, } \\
\text { dengan cara mengatakan } \\
\text { apa adanya, tanpa penilaian } \\
\text { dari orangtua, memberikan } \\
\text { contoh deskripsi kasus, } \\
\text { yang dimulai dengan: } \\
\text { 1. Menuliskan perilaku anak } \\
\text { yang tidak diterima } \\
\text { orangtua } \\
\text { 2. Respon orangtua } \\
\text { terhadap perilaku yang } \\
\text { tidak diterima tersebut } \\
\text { 3. Dampak yang } \\
\text { ditimbulkan }\end{array}$ & $\begin{array}{l}\text { - Orangtua telah menyadari } \\
\text { kekeliruannya yang selalu } \\
\text { menggunakan kata kamu diikuti } \\
\text { dengan kritikan dan kesalahan, tanpa } \\
\text { memberikan kesempatan kepada anak } \\
\text { membela diri. } \\
\text { - Orangtua mau dan mulai menerapkan } \\
\text { keterampilan menggunakan pesan } \\
\text { kamu dengan benar, tanpa diikuti } \\
\text { dengan penilaian atau kritikan, tetapi } \\
\text { melihat permasalahan itu sebagai milik } \\
\text { anak yang memerlukan bantuan } \\
\text { orangtua. }\end{array}$ \\
\hline $\begin{array}{l}\text { Penggunaan } \\
\text { Pesan Saya } \\
\text { dalam } \\
\text { berkomu- } \\
\text { nikasi }\end{array}$ & $\begin{array}{l}\text { Hampir semua } \\
\text { orangtua belum } \\
\text { memahami } \\
\text { pentingnya } \\
\text { menggunakan } \\
\text { bahasa saya dalam } \\
\text { berkomunikasi, dan } \\
\text { mengamati } \\
\text { permasalahan anak } \\
\text { dari sudut pandang } \\
\text { orangtua, tanpa } \\
\text { menimbulkan } \\
\text { masalah pada anak } \\
\text { dan orangtua. }\end{array}$ & $\begin{array}{l}\text { Melatih orangtua } \\
\text { keterampilan menggunakan } \\
\text { pesan saya, dengan } \\
\text { memberikan contoh } \\
\text { deskripsi kasus, yang } \\
\text { dimulai dengan: } \\
\text { 1. Menuliskan perilaku anak } \\
\text { yang tidak diterima } \\
\text { orangtua } \\
\text { 2. Mengungkap perasaan } \\
\text { orangtua terhadap } \\
\text { perilaku yang tidak } \\
\text { diterima tersebut } \\
\text { 3. Menuliskan dampak } \\
\text { nyata yang ditimbulkan } \\
\text { pada orangtua } \\
\text { 4. Menggabungkan butir 1, } \\
\text { 2, dan } 3 \text { menjadi kalimat } \\
\text { dimulai dengan kata } \\
\text { "saya" }\end{array}$ & $\begin{array}{l}\text { - Orangtua telah menyadari } \\
\text { kekeliruannya yang selalu } \\
\text { menggunakan kata "kamu" di dalam } \\
\text { berkomunikasi, padahal dengan } \\
\text { menggunakan kata "saya" jauh lebih } \\
\text { manusiawi, karena memandang anak } \\
\text { sebagai manusia yang siap } \\
\text { berkembang, tanpa meragukan } \\
\text { kemampuannya pandai memecahkan } \\
\text { masalahnya sendiri dan bisa } \\
\text { mengambil keputusan sendiri terhadap } \\
\text { aktivitas-aktivitasnya. } \\
\text { - Orangtua mau dan mulai menerapkan } \\
\text { keterampilan menggunakan pesan } \\
\text { "saya" tanpa penilaian atau kritikan, } \\
\text { terhadap perilaku anak, dengan } \\
\text { memandang perilaku anak tersebut } \\
\text { sebagai fakta yang perlu diubah dan } \\
\text { diperbaiki, tanpa melukai perasaan } \\
\text { anak dan orangtua tetapi melihat } \\
\text { permasalahan itu sebagai milik anak } \\
\text { yang memerlukan bantuan orangtua } \\
\end{array}$ \\
\hline
\end{tabular}

Sumber: LK \& FGD, 2013

Berikut dikemukakan hasil rangkuman pengamatan pelaksanaan pelatihan Model PAO-MKA mulai dari penggalan 1 sampai dengan penggalan 5 yang dirangkum dalam tabel 02 berikut ini. 
Sunarty, implementasi model pola asuh... 47

Tabel 02. Rangkuman Hasil Observasi Pelaksanaan Latihan Model PAO-MKA (N=30)

\begin{tabular}{|c|c|c|c|c|c|c|c|c|c|c|c|c|c|c|}
\hline \multirow[b]{3}{*}{ No. } & \multirow[b]{3}{*}{ Aspek Pengamatan } & \multicolumn{10}{|c|}{ PERTEMUAN KE } & & & \multirow[b]{3}{*}{ KATEGORI } \\
\hline & & \multicolumn{2}{|c|}{$\mathbf{I}$} & \multicolumn{2}{|c|}{ II } & \multicolumn{2}{|c|}{ III } & \multicolumn{2}{|c|}{ IV } & \multicolumn{2}{|c|}{$\mathbf{V}$} & \multicolumn{2}{|c|}{ RERATA } & \\
\hline & & $\mathbf{F}$ & $\%$ & $\mathbf{F}$ & $\%$ & $\mathbf{F}$ & $\%$ & $\mathbf{F}$ & $\%$ & $\mathbf{F}$ & $\%$ & Tot & $\%$ & \\
\hline 1. & $\begin{array}{l}\text { Kehadiran mengikuti } \\
\text { kegiatan }\end{array}$ & 30 & 100 & 30 & 100 & 30 & 100 & 30 & 100 & 30 & 100 & 30 & 100 & Sangat Tinggi \\
\hline 2. & Membaca modul & 27 & 90 & 30 & 100 & 30 & 100 & 30 & 100 & 30 & 100 & 29 & 98 & Sangat Tinggi \\
\hline 3. & Mengajukan pertanyaan & 9 & 30 & 15 & 50 & 21 & 70 & 27 & 90 & 27 & 90 & 20 & 66 & Cukup Tinggi \\
\hline 4. & Mencatat & 24 & 80 & 27 & 90 & 30 & 100 & 30 & 100 & 30 & 100 & 28 & 94 & Sangat Tinggi \\
\hline 5. & Menjawab pertanyaan & 12 & 40 & 15 & 50 & 21 & 70 & 24 & 80 & 30 & 100 & 20 & 68 & Cukup Tinggi \\
\hline 6. & $\begin{array}{l}\text { Mau mendengar } \\
\text { pendapat orang lain }\end{array}$ & 21 & 70 & 18 & 60 & 24 & 80 & 30 & 100 & 30 & 100 & 25 & 82 & Tinggi \\
\hline 7. & Kerjasama & 27 & 90 & 30 & 100 & 30 & 100 & 30 & 100 & 30 & 100 & 29 & 98 & Sangat Tinggi \\
\hline 8. & Memberikan masukan & 12 & 40 & 15 & 50 & 21 & 70 & 24 & 80 & 27 & 90 & 20 & 66 & Cukup Tinggi \\
\hline 9. & Mengerjakan tugas & 30 & 100 & 30 & 100 & 30 & 100 & 30 & 100 & 30 & 100 & 30 & 100 & Sangat Tinggi \\
\hline 10. & Melaporkan tugas & 24 & 80 & 24 & 80 & 30 & 100 & 30 & 100 & 30 & 100 & 28 & 92 & Sangat Tinggi \\
\hline 11. & $\begin{array}{l}\text { Mengikuti kegiatan } \\
\text { berdasarkan tahapan }\end{array}$ & 30 & 100 & 30 & 100 & 30 & 100 & 30 & 100 & 30 & 100 & 30 & 100 & Sangat Tinggi \\
\hline
\end{tabular}

Sumber: Pedoman Observasi

Dengan demikian, melalui observasi dapat disimpulkan bahwa partisipasi para peserta dalam mengikuti pelatihan Model PAO-MKA sangat tinggi. Selanjutnya, hasil yang diperoleh setelah penerapan Model PAO-MKA oleh orangtua, yang terungkap melalui checklist, yang dirangkum dalam tabel 03 , berikut ini.

Tabel 03. Rangkuman Hasil Pelatihan Model PAO-MKA $(\mathrm{N}=30)$

\begin{tabular}{|l|l|l|l|}
\hline No. & \multicolumn{1}{|c|}{$\begin{array}{c}\text { Jenis } \\
\text { Keterampilan } \\
(\text { Penggalan) }\end{array}$} & $\begin{array}{c}\text { Perolehan } \\
\text { (rerata) }\end{array}$ & Kategori \\
\hline 1. & $\begin{array}{l}\text { Mengamati Cara } \\
\text { Pandang Orangtua } \\
\text { dalam } \\
\text { Berkomunikasi, }\end{array}$ & $\begin{array}{l}8,125 \\
(81,25 \%)\end{array}$ & $\begin{array}{l}\text { Sangat } \\
\text { Tinggi }\end{array}$ \\
\hline 2. & $\begin{array}{l}\text { Menggunakan } \\
\text { Bentuk-Bentuk } \\
\text { Komunikasi }\end{array}$ & $8,0(80 \%)$ & Tinggi \\
\hline 3. & $\begin{array}{l}\text { Mengamati Jenis- } \\
\text { Jenis Perasaan } \\
\text { Anak dan } \\
\text { Sikap/Tindakan } \\
\text { Orangtua dalam } \\
\text { Berkomunikasi }\end{array}$ & $8,0(80 \%)$ & Tinggi; \\
\hline
\end{tabular}

\begin{tabular}{|c|c|c|c|}
\hline 4. & $\begin{array}{l}\text { Mendengarkan } \\
\text { Anak dalam } \\
\text { Berkomunikasi }\end{array}$ & $\begin{array}{l}8,25 \\
(82,5 \%)\end{array}$ & $\begin{array}{l}\text { Sangat } \\
\text { Tinggi }\end{array}$ \\
\hline 5. & $\begin{array}{l}\text { Menggunakan } \\
\text { Pesan dalam } \\
\text { Berkomunikasi }\end{array}$ & $\begin{array}{l}8,75 \\
(87,5 \%)\end{array}$ & $\begin{array}{l}\text { Sangat } \\
\text { Tinggi }\end{array}$ \\
\hline \multicolumn{2}{|c|}{$\begin{array}{r}\text { Keterampilan (Penggalan } \\
1 \text { s.d. 5) }\end{array}$} & $\begin{array}{l}8,225 \\
(82,25 \%)\end{array}$ & $\begin{array}{l}\text { Sangat } \\
\text { Tinggi. }\end{array}$ \\
\hline
\end{tabular}

Sumber: Checklist untuk orangtua, 2013

Dengan demikian dapat disimpulkan bahwa Model PAO-MKA telah diterapkan dengan sangat baik oleh orangtua peserta pelatihan.

Keefektifan Model PAO-MKA.Analisis statistik dilaksanakan guna memperoleh gambaran tingkat kemandirian anak sebelum dan sesudah pelatihan dan penerapan Model PAO-MKA oleh orangtua terhadap anaknya. Gambaran tingkat kemandirian Anak sebelum dan setelah eksperimen $(\mathrm{N}=30)$, disajikan dalam Tabel 04 di bawah ini. 
Tabel 04. Gambaran Tingkat kemandirian Anak sebelum dan setelah Implementasi Model PAO-MKA $(\mathrm{N}=30)$

\begin{tabular}{crrrrrrr}
\hline No. & Posttest & Pretest & Gain & No. & Posttest & Pretest & Gain \\
\hline 1. & 165 & 150 & 15 & 16. & 156 & 156 & 0 \\
\hline 2. & 155 & 143 & 12 & 17. & 147 & 147 & 0 \\
\hline 3. & 140 & 134 & 6 & 18. & 180 & 178 & 2 \\
\hline 4. & 182 & 171 & 11 & 19. & 166 & 165 & 1 \\
\hline 5. & 172 & 165 & 7 & 20. & 182 & 178 & 4 \\
\hline 6. & 186 & 180 & 6 & 21. & 133 & 132 & 1 \\
\hline 7. & 148 & 138 & 10 & 22. & 176 & 175 & 1 \\
\hline 8. & 183 & 176 & 7 & 23. & 161 & 160 & 1 \\
\hline 9. & 146 & 142 & 4 & 24. & 160 & 156 & 4 \\
\hline 10. & 157 & 155 & 2 & 25. & 190 & 187 & 3 \\
\hline 11. & 132 & 124 & 8 & 26. & 160 & 156 & 4 \\
\hline 12. & 120 & 114 & 6 & 27. & 138 & 132 & 6 \\
\hline 13. & 163 & 153 & 10 & 28. & 162 & 154 & 9 \\
\hline 14. & 159 & 154 & 5 & 29. & 168 & 158 & 10 \\
\hline 15. & 170 & 154 & 16 & 30. & 172 & 160 & 12 \\
\hline
\end{tabular}

Berdasarkan pada Tabel 04, data dilanjutkan dengan membuat distribusi gambaran menunjukkan bahwa dari 30 anak/anak yang menikuti pretest dan posttest semuanya mengalami peningkatan skor kemandirian. tingkat kemandirian anak sebelum dan sesudah menerima perlakuan model PAO-MKA dari Selanjutnya, data empirik pada tabel 04,

Tabel 05 Distribusi Gambaran Tingkat kemandirian Anak (N=30)

\begin{tabular}{llrrrr}
\hline & Tingkat Kemandirian & Pretest & \multicolumn{3}{c}{ Postetst } \\
\cline { 3 - 6 } Interval & & $\mathrm{F}$ & $\%$ & $\mathrm{~F}$ & $\%$ \\
\hline $178-193$ & Sangat Tinggi & 5 & 16,67 & 6 & 20,00 \\
\hline $162-177$ & Tinggi & 5 & 16,67 & 9 & 30,00 \\
\hline $146-161$ & Cukup & 12 & 40,00 & 10 & 33,33 \\
\hline $130-145$ & Rendah & 6 & 20,00 & 4 & 13.33 \\
\hline $114-129$ & Sangat Rendah & 2 & 6,66 & 1 & 3,34 \\
\hline & Jumlah & 30 & 100,00 & 30 & 100,00 \\
\hline
\end{tabular}

Sumber: Data primer (hasil skala kemandirian) 2013

Berdasar pada data empirik pada tabel 05 tersebut dapat dikemukakan bahwa tingkat kemandirian anak sebelum penerapan model PAO-MKA oleh orangtua, anak mereka berada pada kategori cukup tinggi sampai dengan sangat tinggi diperoleh persentase sebesar $73,34 \%$.

Setelah penerapan Model PAO-MKA oleh orangtua, anak mereka mengalami perubahan, yakni cukup tinggi sampai dengan sangat tinggi diperoleh persentase sebesar 83,33\%. Dengan demikian dapat disimpulkan bahwa Model PAOMKA dapat meningkatkan kemandirian anak. Untuk lebih meyakinkan peningkatan 
kemandirian anak tersebut masih perlu dianalisis lebih jauh untuk mengetahui signifikansi peningkatan tersebut. Oleh karena itu dilakukan analisis statistik inferensial.

Analisis statistik infrensial digunakan untuk menguji keefektifan Model PAO-MKA dalam meningkatkan kemandirian anak. Uji keefektifan Model menggunakan uji t (uji perbedaan Mean) antara pretest (sebelum penerapan Model) dan postetst (setelah penerapan Model), dengan cara membandingkan perbedaan antara hasil pretest dan posttest skala kemandirian. Hipotesis "Apakah Model PAOMKA dapat meningkatkan kemandirian anak?" Untuk pengujian hipotesis, diajukan hipotesis kerja "Ada perbedaan tingkat kemandirian anak sebelum dan sesudah penerapan Model PAOMKA oleh orangtua terhadap anak". Untuk keperluan analisis diajukan hipotesis nihil $\left(\mathrm{H}_{0}\right)$, "Tidak ada perbedaan tingkat kemandirian anak sebelum dan sesudah penerapan Model PAOMKA oleh orangtua terhadap anak". Hasil pengujian hipotesis dirangkum dalam table $07 \mathrm{di}$ bawah ini.

Tabel 06 Hasil Uji t Tingkat Kemandirian Anak $(\mathrm{N}=30)$

\begin{tabular}{ccccccc}
\hline \multicolumn{2}{c}{ Mean } & & & & \\
\cline { 1 - 2 } Pretest & Posttes & & T & Signifikansi & $\mathbf{H}_{\mathbf{0}}$ & $\mathbf{H}_{\mathbf{1}}$ \\
\hline 154.9000 & 160.9667 & & 7.522 & 0,000 & Ditolak & Diterima \\
\hline
\end{tabular}

Berdasarkan hasil penghitungan uji t pada Tabel 09 diperoleh nilai $\mathrm{t}_{\text {hitung }}=7,522(\mathrm{df} 29)$, probabilitas $=0,05$, atau $\alpha 0,05)$, sementara nilai $\mathrm{t}_{\text {tabel }}$ (df 29, probabilitas $=0,05$, atau $\alpha 0,05$ ), diperoleh 2,042. Hasil ini menunjukkan bahwa nilai $\mathrm{t}_{\text {hitung }}$ lebih besar daripada nilai $\mathrm{t}_{\text {tabel }}(7,522>$ 2,042). Hal ini berarti bahwa hipotesis yang berbunyi "Tidak ada perbedaan tingkat kemandirian anak sebelum dan sesudah penerapan Model PAO-MKA oleh orangtua terhadap anak", ditolak, sehingga hipotesis kerja $\left(\mathrm{H}_{1}\right)$ yang berbunyi "Ada perbedaan tingkat kemandirian anak sebelum dan sesudah penerapan Model PAO-MKA oleh orangtua terhadap anak", diterima. Dengan adanya perbedaan tingkat kemandirian anak sebelum dan sesudah penerapan Model PAO-MKA oleh orangtua, dapat disimpulkan bahwa penerapan Model PAO-MKA dapat meningkatkan kemandirian anak. Dengan demikian Model PAO-MKA dinyatakan efektif meningkatkan kemandirian anak.

\section{Pembahasan}

Penerapan Model PAO-MKA melalui pelatihan (eksperimen) menunjukkan hasil bahwa Model tersebut ternyata dapat meningkatkan kemandirian anak. Persoalannya, betulkah peningkatan kemandirian anak disebabkan oleh penerapan Model PAO-MKA? Jika betul mengapa peningkatan itu bisa terjadi? Untuk menjawab pertanyaan itu, dilakukan penelusuran data lebih lanjut dengan cara melakukan wawancara terhadap tiga anak yang memperoleh gain score kemandirian yang masuk kategori tinggi, sedang, dan rendah bersama dengan orangtuanya.

Wawancara kepada orangtua anak dilaksanakan pada tanggal 10 Agustus 2013, secara bergiliran di ruang kerja Guru Bimbingan dan Konseling (Guru BK) SMP Negeri 8 Makassar. Dari analisis data wawancara ditemukan bahwa orangtua yang berpartisipasi aktif dalam mengikuti pelatihan Model PAOMKA, memahami, bersedia, dan dapat menerapkan hal-hal yang dialami dalam pelatihan Model tersebut terhadap anaknya di rumah. Pada diri orangtua terjadi perubahan cara pandang dan cara memperlakukan anak atau memperbaiki pola asuh sesuai dengan tahapan perkembangan anak. 
Perubahan yang dirasakan oleh orangtua, tergambar pada ungkapan-ungkapan orangtua ketika diajukan pertanyaan, dirangkum dalam tabel 07, sebagai berikut:

Tabel 07. Rangkuman Hasil Wawancara Orangtua Anak (N=3)

\begin{tabular}{|c|c|c|c|c|}
\hline \multirow{2}{*}{ No. } & \multirow{2}{*}{ Pertanyaan } & \multicolumn{3}{|c|}{ Respon Orangtua } \\
\hline & & NR & AR & YS \\
\hline 1 & $\begin{array}{l}\text { Adakah perbedaan } \\
\text { komunikasi yang Ibu } \\
\text { lakukan antara } \\
\text { sebelum mengikuti } \\
\text { latihan Model PAO- } \\
\text { MKA dengan sesudah } \\
\text { mengikuti latihan } \\
\text { Model PAO-MKA? }\end{array}$ & $\begin{array}{l}\text { "ada... saya banyak } \\
\text { belajar tentang cara } \\
\text { berbicara dan } \\
\text { bertindak yang } \\
\text { dapat diterima } \\
\text { anak, .. saya tidak } \\
\text { lagi memaksakan } \\
\text { kehendak ... dan } \\
\text { saya tidak terlalu } \\
\text { mengatur anak } \\
\text { saya.... }\end{array}$ & $\begin{array}{l}\text { "saya banyak mencoba } \\
\text { menerap-kan hasil } \\
\text { pelatihan ..., saya banyak } \\
\text { berkomunikasi dengan } \\
\text { anak, saya mengurangi } \\
\text { doktrin terhadap anak..., } \\
\text { saya 50ember kebebasan } \\
\text { tetapi tetap mengawasi ,., } \\
\text { dan saya mencoba belajar } \\
\text { mengalah jika } \\
\text { dibutuhkan... }\end{array}$ & $\begin{array}{l}\text { “... banyak sekali } \\
\text { yang saya } \\
\text { dapat... meskipun } \\
\text { sulit untuk } \\
\text { berubah total, } \\
\text {...tetapi... } \\
\text { minimal saya } \\
\text { sudah tahu cara } \\
\text { yang lebih baik } \\
\text { dalam mendidik } \\
\text { anak }\end{array}$ \\
\hline 2. & $\begin{array}{l}\text { "Apa perubahan yang } \\
\text { Ibu rasakan setelah } \\
\text { mengikuti pelatihan } \\
\text { Model PAO-MKA?" }\end{array}$ & $\begin{array}{l}\text { "... saya tidak lagi } \\
\text { memaksa-kan } \\
\text { kehendak... dan } \\
\text { saya tidak terlalu } \\
\text { mengatur anak } \\
\text { saya...." }\end{array}$ & $\begin{array}{l}\text { “...saya memberi } \\
\text { kebebasan tetapi tetap } \\
\text { mengawasi ,,,,dan saya } \\
\text { mencoba belajar } \\
\text { mengalah... jika } \\
\text { dibutuhkan... }\end{array}$ & $\begin{array}{l}. . . \text { saya jauh } \\
\text { lebih mengerti } \\
\text { kondisi anak... } \\
\text { saya lebih } \\
\text { lembut... dan } \\
\text { lebih mau } \\
\text { memerhatikan } \\
\text { kondisi anak }\end{array}$ \\
\hline 3. & $\begin{array}{l}\text { "Manfaat apa yang } \\
\text { diperoleh dari } \\
\text { pelatihan Model PAO- } \\
\text { MKA?" }\end{array}$ & $\begin{array}{l}\text { "... saya lebih baik } \\
\text { dalam } \\
\text { berkomunikasi } \\
\text { dengan anak...." }\end{array}$ & $\begin{array}{l}\text { “... saya lebih efektif } \\
\text { dalam berkomunikasi } \\
\text { dengan anak...”" }\end{array}$ & $\begin{array}{l}\text { “... saya rasanya } \\
\text { berubah dari } \\
\text { orangtua yang } \\
\text { ketat menjadi } \\
\text { orangtua yang } \\
\text { lebih komunikatif }\end{array}$ \\
\hline
\end{tabular}

(Wawancara, 10 Agustus 2013).

Wawancara terhadap anak, dilaksanakan pada tanggal 13 Agustus 2013, secara bergiliran, pertanyaan, dirangkum dalam tabel 08 sebagai di ruang Guru BK SMP Negeri 8 Makassar. Perubahan yang dirasakan oleh orangtua, juga diakui oleh anak/anak ketika diajukan berikut: 
Sunarty, implementasi model pola asuh... 51

Tabel 08. Rangkuman Hasil Wawancara Orangtua Anak (N=3)

\begin{tabular}{|c|c|c|c|c|}
\hline \multirow[b]{2}{*}{ No. } & \multirow[b]{2}{*}{ Pertanyaan } & \multicolumn{3}{|c|}{ Respon Anak } \\
\hline & & $\begin{array}{c}\text { Iren (nama } \\
\text { samaran) } \\
\end{array}$ & Adi (nama samaran) & Ria (nama samaran) \\
\hline 1 & $\begin{array}{l}\text { Adakah } \\
\text { perubahan } \\
\text { perlakuan } \\
\text { orangtua } \\
\text { setelkah } \\
\text { orangtua } \\
\text { mengikuti } \\
\text { pelatihan } \\
\text { (8 minggu) }\end{array}$ & $\begin{array}{l}\text { "Ya, meskipun } \\
\text { masih kadang- } \\
\text { kadang keras begitu, } \\
\text { sekarang sudah } \\
\text { mending-an, Ibu } \\
\text { saya sudah mau } \\
\text { mendengar, tidak } \\
\text { keras lagi, mulai } \\
\text { sering bertanya } \\
\text { sebelum ibu } \\
\text { melarang... atau } \\
\text { menyetujui"" } \\
\text { "Kalau bapak masih } \\
\text { seperti yang dulu... } \\
\text { tetapi kalau ibu } \\
\text { sudah setuju, bapak } \\
\text { biasanya tidak berko- } \\
\text { mentar apa-apa. } \\
\text { Padahal dulu bapak } \\
\text { dan Ibu baku ceeski. } \\
\text { Maksud saya } \\
\text { kompakki Bu... tidak } \\
\text { saling beda pendapat. } \\
\text { "Sekarang orangtua } \\
\text { saya mau dengar, } \\
\text { tidak keras lagi, } \\
\text { kalau bicara tidak } \\
\text { mendo-minasi lagi, } \\
\text { suaranya tidak lagi } \\
\text { bernada tinggi seperti } \\
\text { yang dulu-dulu... }\end{array}$ & $\begin{array}{l}\text { "Kalau saya } \\
\text { perhatikan ... Ibu dan } \\
\text { bapak saya ... } \\
\text { kayaknya ... bedaki } \\
\text { dibandingkan dengan } \\
\text { yang dulu-dulu ..." } \\
\text { "Sekarang dia agak } \\
\text { peduli dengan saya ... } \\
\text { tidak kasar, dulu agak } \\
\text { menjeng-kelkan ... } \\
\text { jadi malaska bicara." } \\
\text { "Dulu ... dia ... } \\
\text { banyak melarang dan } \\
\text { menuntut, sedikit- } \\
\text { sedikit tidak boleh ..., } \\
\text { pokoknya dulu } \\
\text { menjengkelkan" } \\
\text { "Sekarang, meskipun } \\
\text { masih kadang-kadang } \\
\text { memaksa begitu, } \\
\text { sudah ... mendingan. } \\
\text { Ibu sering bertanya } \\
\text { sebelum mela-rang ... } \\
\text { dan sudah enak diajak } \\
\text { ngobrol". "Ibu mulai } \\
\text { mendengar kalau saya } \\
\text { bercerita ... tidak } \\
\text { terlalu banyak lagi } \\
\text { mengatur, tidak kaku } \\
\text { lagi ..." "Bapak } \\
\text { begitu juga bu. Bapak } \\
\text { dan Ibu kayaknya } \\
\text { tidak beda, semuanya } \\
\text { baik ..." }\end{array}$ & $\begin{array}{l}\text { "Kalau saya perhatikan } \\
\text { akhir-akhir ini Ibu dan } \\
\text { Bapak saya ... agak lain } \\
\text {... kayak ada yang beda } \\
\text { dibandingkan dengan } \\
\text { yang dulu-dulu". } \\
\text { "Sekarang Ibu dan } \\
\text { Bapak agak peduli } \\
\text { dengan saya ... kalau } \\
\text { saya minta izin sudah } \\
\text { mulai bertanya mau ke } \\
\text { mana..." } \\
\text { "Orangtua sudah tidak } \\
\text { memaksakan lagi apa } \\
\text { maunya ... meskipun } \\
\text { kadang-kadang masih } \\
\text { agak otoriter..." } \\
\text { "Sesekali ... masih... } \\
\text { banyak tanya ... sebelum } \\
\text { menyetujui permintaan } \\
\text { saya .... juga } \\
\text { menanyakan tentang } \\
\text { keadaan di sekolah ...” } \\
\text { "Meskipun ibu masih } \\
\text { kadang-kadang banyak } \\
\text { tanya, sekarang sudah } \\
\text { mendingan. Ibu sering } \\
\text { bertanya sebelum } \\
\text { melarang... dan sekarang } \\
\text { enak diajak ngobrol ...” } \\
\text { "Saya merasa lebih } \\
\text { dihargai, lebih banyak } \\
\text { melakukan aktivitas } \\
\text { sendiri tanpa bantuan } \\
\text { orang lain, dan percaya } \\
\text { atas kemampuan sendiri }\end{array}$ \\
\hline 2. & $\begin{array}{l}\text { Apa dampak } \\
\text { yang terjadi } \\
\text { pada dirimu } \\
\text { setelah } \\
\text { orangtua } \\
\text { mengikuti } \\
\text { pelatihan } \\
\text { Model PAO- }\end{array}$ & $\begin{array}{l}\text { "Ya, saya lebih } \\
\text { terbuka kepada kedua } \\
\text { orangtua saya, saya } \\
\text { lebih percaya diri, } \\
\text { saya lebih berani } \\
\text { melakukan banyak } \\
\text { hal tanpa takut salah } \\
\text { lagi" }\end{array}$ & $\begin{array}{l}\text { "Saya lebih ... happy } \\
\text {.. karena tidak } \\
\text { merasa diawasi terus } \\
\text {... kayak orang yang } \\
\text { membuat kesalahan } \\
\text {..." "Pokoknya saya } \\
\text { merasa plong ..." } \\
\text { "Saya merasa banyak }\end{array}$ & $\begin{array}{l}\text { "Saya merasa lebih } \\
\text { berharga karena lebih } \\
\text { diperhatikan ,.. merasa } \\
\text { lebih percaya diri dan } \\
\text { lebih menyadari } \\
\text { kemampuan diri, lebih } \\
\text { banyak melakukan } \\
\text { aktivitas tanpa bantuan }\end{array}$ \\
\hline
\end{tabular}

Program Pascasarjana Universitas Negeri Makassar

Copyright@2015 - JEST 
Sunarty, implementasi model pola asuh... 52

\begin{tabular}{lll}
\hline MKA & hal yang saya dapat & orang lain, dan lebih \\
& lakukan sendiri ... & percaya diri atas \\
& tanpa menunggu \\
perintah dari & kemampuan sendiri” \\
& orangtua" & \\
\hline
\end{tabular}

(Wawancara, 13 Agustus 2013).

Dari ungkapan-ungkapan orangtua dan anak tersebut, dapat disimpulkan bahwa peningkatan kemandirian anak disebabkan oleh adanya perubahan polah asuh orangtua pascapenerapan Model PAO-MKA. Perubahan pola asuh tersebut berimbas pada terjadinya peningkatan kemandirian anak. Terjadinya peningkatan kemandirian anak disebabkan oleh karena anak merasa lebih diperhatikan dibandingkan sebelum adanya perlakuan Model PAO-MKA.

\section{SIMPULAN DAN SARAN}

Penerapan model PAO-MKA di lapangan terbukti efektif dalam meningkatkan kemandirian anak. Keefektifan itu dimungkinkan terjadi karena penerapan model PAO-MKA dapat mengubah cara pandang, sikap, dan perilaku kepengasuhan orangtua terhadap anaknya. Sementara itu, perubahan yang terjadi pada orangtua dipersepsi positif oleh anak mereka sehingga terjalin komunikasi yang baik, wajar, koperatif, dan terbuka antara orangtua dan anaknya. Perubahan perilaku ucapan dan tindakan orangtua dalam berkomunikasi, bertransaksi atau berinteraksi menjadikan anak merasa lebih dihargai dan lebih dipercayai terhadap aktivitas yang dilakukannya, sehingga anak merasa bebas dalam mengambil keputusan dan bertanggung jawab terhadap keputusannya.

Penerapan Model PAO-MKA di lapangan terbukti efektif dalam meningkatkan kemandirian anak. Oleh karena itu, disarankan agar para pendidik (guru atau guru BK) menyosialisasaikan Model PAO-MKA kepada para orangtua anak. Selain itu, pihak sekolah, dalam hal ini kepala sekolah diharapkan menetapkan kebijakan dan pembagian alokasi dana untuk penyediaan sarana pendukung pelaksanaan pelatihan dan pendampingan orangtua anak di sekolah. Alokasi dana diperlukan terutama dalam kaitannya dengan pelaksanaan kegiatan-kegiatan sosialisasi pengasuhan anak dan penyediaan buku-buku atau bahan-bahan informasi lain tentang pengasuhan anak, khususnya pengasuhan anak dalam latar psikologi, pendidikan, dan bimbingan. Di samping itu, teoretisi dan pengembang dalam bidang bimbingan dan konseling perlu menggalakkan atau mengimplementasi-kan Model PAO-MKA dalam konteks yang lebih beragam dan populasi yang lebih luas, dan menekankan pertimbangan-pertimbangan budaya lokal dalam pemilihan sampel penelitian.

\section{DAFTAR RUJUKAN}

Al- Istanbuli, M. M. 2006. Parenting Guide: Dialog Imajiner tentang Cara Mendidik Anak Berdasarkan Al-Quran, As-Sunah, dan Psikologi. Jakarta: Hikmah Kepustakaan Populer

Ali, M., \& Asrori, M. 2008. Psikologi Remaja: Perkembangan Peserta Didik. Jakarta: Bumi Aksara.

Astuti, P. W. 2009. Peranan Pola Asuh Orang Tua terhadap Pembentukan Kemandirian Belajar Peserta Didik SMK PGRI I Taman Kabupaten Pemalang Tahun Pelajaran 2008-2009. Skripsi. Tidak Diterbitkan. Tegal: FKIP UPS Tegal.

Astuti. R. D. 2005. Pengaruh Pola Asuh Orangtua terhadap Kemandirian Anak dalam Belajar pada Anak Kelas XI SMA Negeri Sumpiuh Kabupaten Banyumas Tahun Pelajaran 2005/2006. Skripsi. Tidak Diterbitkan. Bandung: Universitas Pendidikan Indonesia.

Dariyo, A. 2007. Psikologi Perkembangan: Anak Tiga Tahun Pertama. Jakarta: Reflika Aditama. 
Sunarty, implementasi model pola asuh... 53

Depdiknas. 2000. Kamus Besar Bahasa Indonesia. Jakarta: Balai Pustaka.

Desmita. 2009. Psikologi Perkembangan Peserta Didik: Panduan bagi Orang Tua dan Guru dalam Memahami Psikologi Anak Usia SD, SMP, dan SMA. Bandung: Remaja Rosdakarya.

Eviana. 2004. Kemandirian sebagai Kebutuhan Psikologis pada Siswa. Yogyakarta: UGM.

Gordon. 2000. Parent Effective Traing: The Proven Program for Raising Responsible Children. New York: Random House Inc.

James, M. 2002. It's Never Too Late to Be Happy. Massachusetts: AddisonWesley Publishing Company, Inc.

Latifatul, C. 2011. Perbedaan Kemandirian Remaja di SMA Negeri 2 Malang Ditinjau dari Urutan Kelahiran. Skripsi. Tidak Diterbitkan. Malang: Universitas Negeri Malang.

Marjohan. 2009. Kemandirian dalam Belajar Perlu Ditingkatkan. IPNU, IPPNU Tangkil Tengah, Senin, 16 Nopember 2009.

McMillan, J. H. \& Schumacher, 1993.. Research in Education: A Conceptual Introduction. Third Edition. New York: Harper Collins College publisher.

Rahmawati. 2005. Perbedaan Kemandirian antara Anak Sulung dengan Anak Bungsu pada Siswa Kelas II SMA Negeri 11 Semarang, Tahun Pelajaran 2004/2005. Skripsi. Tidak Diterbitkan. Semarang: Universitas Negeri Semarang.

Santrock, J. W. 2009. Psikologi Pendidikan Educational Psychology. Edisi Ketiga Buku 1. Terjemahan Diana Angelica. Jakarta: Salemba Humanika.

Sunarty, K. 2014. Model Pola Asuh Orangtua untuk Meningkatkan Kemandirian Anak. Disertasi. Tidak Diterbitkan. Makassar: Universitas Negeri Makassar.

Program Pascasarjana Universitas Negeri Makassar
Suryono, Y. 2013. Pudarnya Kemandirian Bangsa: Adakah Peran Pendidikan dan Ilmu Pendidikan?. Yogyakarta: Ash-Shaff. 